\title{
An Exploration Of Theoretical Foundations For Working Mothers' Formal Workplace Social Networks
}

Jennifer L. Schultz, Metropolitan State University, USA

Jeanne L. Higbee, University of Minnesota, USA

\begin{abstract}
This paper presents a multidisciplinary integrative exploratory review of possible theoretical foundations for working mothers' formal workplace social networks. Beginning with theoretical overviews of work-life balance, career development, mentoring, psychology, and social capital this paper develops a plausible possible framework rooted in women's psychological developmental theory. The authors conclude that the theoretical frameworks for human resource development (HRD) and human resource management (HRM) do not identify one unified specific framework for research and scholarly investigation of working mothers' formal workplace social networks, while presenting a conceptual model grounded in Gilligan's (1982) principles appears to be a good fit for enhancing the understanding of the phenomenon.
\end{abstract}

Keywords: women, Gilligan, working mothers, social networks, work-life balance

\section{INTRODUCTION}

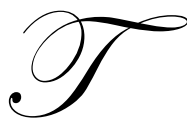

he purpose of this paper is to examine the literature on theoretical perspectives of formal workplace networks and support groups for working mothers. The aim is to provide a foundation for a conceptual framework that supports the usefulness of these networks in organizational contexts, in order to provide a contemporary scaffold that supports the impetus for needed research on this topic.

Balancing work and family is a significant social and human development challenge of our time (Halpern, 2005) and is a critical productivity factor in many organizations. According to Grzywacz and Carlson (2007), it is also a central issue for the field of HRD. Employed mothers constitute a heterogeneous group in many ways and on many levels (Paludi \& Neidermeyer, 2007), with no generally accepted empirical theories or models to explain the personal and professional developmental needs unique to working mothers (Zedeck \& Mosier, 1990). For business leaders to remain competitive globally, it is important that they align work and family issues with corporate culture, using work and family concerns as levers for change (Wentling, 1998). Developing a theoretical framework for understanding the role of support networks for working mothers is critical to future endeavors in creating viable networks and assessing their effectiveness for both participants and employers.

\section{THEORY IDENTIFICATION}

Work and family are socializing forces (Edwards \& Rothbard, 2000). Research on this topic has been published in a variety of fields, including management, psychology, and family science, with the scholarship in each field based on a variety of theoretical approaches (Morris \& Madsen, 2007). Work-family research is inherently multidisciplinary (Pitt-Catsouphes, Kossek, \& Sweet, 2006), embracing every social science and professional discipline prompting the need for identification, naming, conceptualization, deconstruction, segmentation, research, discussion, and program evaluation (Kanter, 1983). Identifying a single theoretical foundation is impossible because working mothers are a heterogeneous group and situated, from a research perspective, in multidisciplinary and multidimensional frameworks. Instead, we propose that possible conceptualizations may be related to the following 
theoretical underpinnings: (a) work-life balance theory, (b) women's development theory, and (c) social capital and social network theory.

\section{Work-life Balance Theories}

The intersection of work and family research is fundamentally challenged by a lack of commonly accepted basic language and key constructs; no single prevailing framework or perspective is universally accepted (PittCatsouphes et al., 2006). The academic body of knowledge regarding work-family scholarship relies on a variety of theoretical frameworks (Morris \& Madsen, 2007), which include spillover, compensation, resource drain, enrichment, congruence, work-family conflict, segmentation, facilitation, integration, and ecology theories (Clark, 2000; Edwards \& Rothbard, 2000; Frone, 2003; Frone, Russell, \& Cooper, 1992; Greenhaus \& Powell, 2006; Zedeck \& Mosier, 1990).

Spillover

Spillover refers to the effects of work and family on each other, and is described in terms of affect (mood and satisfaction), values (importance of work and family), and skills (Edwards \& Rothbard, 2000). The experiences resulting from spillover can manifest themselves as either positive or negative (Morris \& Madsen, 2007). The majority of research in the area of work-family frameworks has been done using spillover theory (Zedeck \& Mosier, 1990). In the literature, spillover has also been termed generalization, isomorphism, continuation, extension, familiarity, and similarity (Edwards \& Rothbard, 2000; Staines, 1980; Zedeck, 1992). There are two interpretations of spillover (Edwards \& Rothbard, 2000): (a) the positive association between family and work satisfaction and family and work values (Zedeck, 1992) and (b) transference in entirety of skills and behaviors between domains (Repetti, 1987) such as when fatigue from work is exhibited at home or when family demands interfere with work schedule.

\section{Compensation}

Compensation theory refers to the efforts aimed at countering negative experiences in one domain through increased efforts for positive experiences in another domain. An example would be a dissatisfied worker focusing more on family than work, thereby reallocating human resources (Edwards \& Rothbard, 2000). According to Zedeck and Mosier (1990), compensation can be viewed in two broad categories: supplemental and reactive. Supplemental compensation occurs when positive experiences are insufficient at work and are therefore pursued at home. Reactive compensation occurs when negative work experiences are made up for in positive home experiences (Zedeck \& Mosier). In other words, according to compensation theory, there is an inverse relationship between work and family, so workers attempt to satisfy voids from one domain with satisfactions from the other (Clark, 2000).

\section{Resource drain}

Resource drain theory refers to the transfer of resources from one domain to another; because resources are limited (e.g., time, money, and attention), available resources in the original domain are reduced (Morris \& Madsen, 2007). Resources can also be shifted to other domains that are not work and family related, such as community or personal pursuits (Edwards \& Rothbard, 2000).

\section{Enrichment}

Enrichment theory refers to the degree to which experiences from instrumental sources (skills, abilities, values) or affective sources (mood, satisfaction) enhance the quality of the other domain (Morris \& Madsen, 2007). Greenhaus and Powell (2006) defined enrichment as "the extent to which experiences in one role improve the quality of life in the other role" (p. 73) and reported that employees perceive that their work and family roles enrich each other. Zedeck and Mosier (1990) used the term instrumental to characterize this concept, which states that good work outcomes lead to good family outcomes and vice versa. 


\section{Congruence}

Congruence theory refers to how additional variables that are not directly related to work or family influence the balance of multiple roles. While spillover is a direct influence between work and family, congruence attributes similarity through a third variable, such as personality traits, behavioral styles, genetic forces, and sociocultural forces (Edwards \& Rothbard, 2000; Staines, 1980; Zedeck, 1992). For example, based on congruence theory, a third variable such as intelligence or level of education could positively influence both work and family domains.

\section{Inter-role conflict}

Inter-role conflict theory refers to what occurs when meeting the demands in one domain makes it difficult to meet the demands in the other domain (Greenhaus \& Beutell, 1985). In the literature, this has also been termed opposition or incompatibility theory (Edwards \& Rothbard, 2000). Greenhaus and Beutell (1985) described eight propositions where the constructs are in conflict in relation to time, role strain, and specific behavior, as follow:

1. Pressures must come from both work and family.

2. Self-identification with roles is necessary.

3. Role salience moderates relationships and is positively related to conflict level.

4. Conflict is strongest when there are negatives associated with non-compliance.

5. Directionality is based on conflict source.

6. Conflict is related to career success and stage.

7. External support is related to conflict.

Segmentation

Segmentation theory refers to viewing work and family as separate domains that do not influence each other. Since the industrial revolution, work and family have been inherently separate by time, space, and function. Piotrkowski (1979) described this process as what occurs when people actively suppress work-related thoughts, feelings, and behaviors in the family domain, and vice versa. As this has been proven no longer to be true (Kanter, 1977) and perhaps never was, particularly for female workers, segmentation is now referred to as the active process that people use to create and maintain boundaries between work and family. The literature also reports the usage of the terms compartmentalization, independence, separateness, disengagement, neutrality, and detachment to describe this theory (Edwards \& Rothbard, 2000).

\section{Facilitation}

Facilitation theory refers to what occurs when the participation in one domain fosters and enhances the engagement in another domain. This portability of augmentation can include skills, experiences, resources, and knowledge (Edwards \& Rothbard, 2000). According to Grzywacz (2002), facilitation occurs because social systems naturally utilize available means to improve situations without regard for domain restrictions.

\section{Integration}

Integration theory refers to the holistic view that a healthy system of flexible and permeable boundaries can better facilitate and encourage the family-life, work-life, and community-life domains (Clark, 2000). Morris and Madsen (2007) acknowledged that integration theory best describes the incorporation of additional contextual elements, such as community, into the body of knowledge regarding work and family. Integration calls for contemporary understandings that retool traditional work-life paradigms, making all stakeholders (employers, workers, and communities) active partners with equal voices in the creation of a holistic model of work-life balance (Morris \& Madsen, 2007). Googins (1997) believed that an approach to work and family that includes all parties and shared responsibility will yield greater results in both domains than solutions created in isolation. 


\section{Ecology}

Ecological systems theory refers to the suggestion that work and family are a joint function of process, person, context, and time characteristics, and symptomatic of the fact that each and multiple characteristics yield an additive consequence on the work life experience (Grzywacz \& Marks, 2000). Ecology theory was later developed into the person-in-environment theory with the common thread among different person environment variants as the recognition that individuals and groups have dynamic relationships with their social, physical, and natural environments (Pitt-Catsouphes et al., 2006).

\section{Women's Developmental Theories}

Three pertinent theoretical areas related to women's development are career development, mentoring and psychology.

\section{Career development}

Women's career choice and career development processes are unique and different from those of men due to social contexts of role and expectations (Schreiber, 1998). Women's traditional roles in homemaking and mothering influence their career choice and adjustment (Fitzgerald, Fassinger, \& Betz, 1995), making current career development models inconsistent with women's experiences, along with the lack of research specific to women's careers (Super, 1957). In short, the success of women's career development will be manifested in the linkage of family needs and community responsibilities to career decisions, so as to balance both roles (Wentling, 1998).

\section{Mentoring}

Human resource management (HRM) literature refers to social support in the context of formal and informal mentoring. The mentoring literature has focused primarily on male experiences (Levinson, 1978; Lyness \& Thompson, 2000) yet the mentor relationship can be one of the most developmentally significant interactions for an employee. The mentoring relationship originally focused on career advancement and upward mobility (Kanter, 1977), but is now considered to be both psychosocial and career development, which are mutually important for an effective relationship (Kram, 1985). Later research by Higgins and Kram (2001) acknowledged that employees are mentored by many different people at differing times. Mentoring is process oriented and developmentally holistic, yet the research and current interventions use male-centric models.

\section{Psychology}

In both the fields of work-life integration and career development, existing theories, models, and frameworks are inherently male engendered or degendered and do not allow for an understanding of social support networks for working mothers, which by definition must be exclusively engendered. We propose that psychological theory can best provide a framework for this experience because, according to Gilligan (1982) and Berger (1994), if we are going to study the experience of women, we must acknowledge the inner sense of connection to others as a central organizing feature of women's development. Miller (1976) pointed to the fact that women's sense of self and worth is grounded in their ability to make and maintain relationships; women generally derive a sense of value and effectiveness from experiences that lead to connection rather than separateness. Relationships are significant for most women, and it is through relational interactions with other people that women develop, although some can develop in isolation. We propose that a theoretical foundation for support networks for working mothers may be found in the work of Gilligan (1982), based on the view that women's development is grounded and defined in their connectedness to self and others.

Gilligan's (1982) developmental model includes four levels: (a) orientation to individual survival, (b) selfsacrifice, (c) goodness, and (d) nonviolence. The orientation to individual survival occurs when individuals perceive themselves as powerless and are concerned only with themselves. From this developmental phase, a woman would then transition to responsibility and then to an understanding of others' needs and feelings. At this developmental point the person in transition decides that it is responsible and mature to think about others and selfish and immature 
to act based on personal desire. However, she will still blame others rather than take responsibility for her own actions. During the next developmental level, self-sacrifice, the moral agent determines that being good means sacrificing for the good of others. She will then perceive herself as good if she is being the caretaker, and she considers herself responsible for the actions of others while holding others responsible for the choices that she makes. Next, the transition to goodness occurs when the person decides that considering oneself in moral decisions is not selfish, but honest. The moral agent develops a new sense of herself as someone also worthy of consideration. She is no longer dependent on outside perceptions of herself as caretaker. The final level is nonviolence, where the moral agent is no longer troubled by a perceived conflict of caring for self versus caring for others, and caring is automatically understood to include others and self. The person accepts nonviolence as the ultimate principle; being mature means minimizing pain and harm for everyone (Gilligan, 1982).

\section{Social Theories}

Two conceptual frameworks related to women's development that are relevant to this research project are social capital and social network theories.

\section{Social capital and social networks}

Social capital is defined by Coleman (1988) in three forms: obligations and expectations, information channels, and social norms. The work environment is one way that social capital can be accumulated through information channels, as well as through the socially accepted norm of employment. The social capital associated with work can be viewed as a factor that facilitates informed action (e.g., consumer choices, investments, earning money) while impeding other behavior (e.g., criminal activity). Social capital can be accumulated through other avenues, such as education, church, and volunteering, but when it is gained through the work experience it is differentiated and unique. There is also a social good and acceptability component to social capital that explains the wider societal benefits to employment.

The strategic imperative of relationship building is theoretically tied to both human capital theory and social exchange theory. There is a unique trait operating in the workplace that is congruent with Gouldner (1959), who stated that our existence is inherently social, meaning that our functional realities are always dependent upon a perceived obligation to return or repay perceived debts that we have received from organizations and individuals. This perception of social reciprocity creates a normative attachment among people and infuses within workers an unwritten obligation to return to the organization any benefits that they have received. Through building and sustaining relationships, employees may perceive a stronger organizational commitment and obligation to return investments to the enterprise.

The development of a conceptual framework for workplace social networks for mothers appears to be tied structurally to capital. The role of the HRD practitioner in this context is to act as a catalyst for organizational and individual capital or capacity for capital. This means that the facilitation of social networks for working mothers has the potential to change physical, economic, financial, social, cultural, human, or intellectual capital for the worker.

Social capital, in learning organization language, refers to the theory that mechanizes an organization as a whole to be more than the parts. It is through the relationship connections that capital is increased with regard to trust, mutual understanding, shared values, and behaviors, thus making the normative connection of members for cooperative mobilization. Social capital is what connects people and supports collaboration, organization commitment, and knowledge creation, and organizations need to provide environments that support both temporal and special connections (Cohen \& Prusak, 2001). This connection is also seen in the work of Watkins and Marsick (1992), who described a triangulation between strategic HRD, social capital accumulation, and learning organization theory.

\section{THEORY EVALUATION}

We propose that work-life integration and career development theories have been found to be structurally weak as frameworks to explore social support networks for working mothers, primarily due to four reasons: (a) 
separateness of constructs, (b) lack of assessment instruments, (c) research completed without theoretical foundations, and (d) male-oriented models of development. In many of the theoretical approaches, and specifically in segmentation and compensation theory, the relationships between work and family constructs are treated as separate and distinct concepts (Morris \& Madsen, 2007), which fundamentally excludes additional contexts such as community (Voydanoff, 2005). Another weakness of existing work-life balance theories is the lack of generally accepted empirical work to non-work interface models that are well documented in the literature and specifically noted by Zedeck and Mosier (1990), where all models are basically descriptive. This weakness is difficult to overlook, because to be of the most value to research, theory, and practice, frameworks should be usable and empirically refutable (Bacharach, 1989).

Another weakness in work-life balance theories is the difficulty the field of HRD has had in capitalizing on work-life theory because it has not kept pace with interest; also, there is not currently an instrument to assess workfamily balance using a unified theoretical foundation (Grzywacz \& Carlson, 2007). The main challenge in evaluating work-life balance theories begins with semantics and differing conceptions of the term balance (Greenhaus \& Allen, 2006), which makes it difficult then to situate research within a theoretical framework, thereby making measurement and evaluation virtually impossible (Grzywacz \& Carlson, 2007). Utilizing the definition of work-family balance as presented by Grzywacz and Carlson as the "accomplishment of role-related expectations that are negotiated and shared between an individual and his or her role-related partners in the work and family domains" (p. 458), work-life balance is then a social rather than a psychological construct that gets its meaning from outside of the individual; a focus on the inherently interactional aspects of the work-life experience is essential for accurate characterization (Grzywacz \& Carlson, 2007).

In addition, weaknesses are found in the literature through the domination of quantitative information focused on supervisory roles, specific corporate interventions, policies, and gender differences, all done with little regard for conceptual frameworks, let alone theory. Clark (2000) identified this void, and began working on a model to better explain the multifaceted relationship of work and non-work that is inclusive of human interaction, meaning creation, and the complexity of work and home situations.

Existing models are also male oriented and do not sufficiently fit female development patterns unique to working mothers. It is clear that many women develop, achieve, and are motivated in different ways than their male counterparts. Current work to non-work interface and career development theories are based on male ideals and tested in male-dominated environments. Until now, the study of individual and organizational behavior has been exclusively and elusively engendered. An exception is the research of the Hawthorne studies. Experiments carried out by George Elton Mayo on human behavior at the Hawthorne Works of the Western Electric Company placed an emphasis on the intrinsic nature of work and concluded that recognition, security, and belonging influence the morale and productivity of workers (Miner, 2002). We propose that a major weakness in current conceptual understandings of working mothers is the fact that male researchers have written about male employees, in maledominated enterprises, resulting in theories devoid of engenderization.

Women's psychological theory and social capital theory appear to address some of the shortcomings of work-life balance and career development theory. Gilligan's (1982) theoretical approach is inherently engendered. When coupled with the fact that social capital, social network theory, and women's moral development theory are also more holistic approaches to understanding when taken together these theoretical frameworks create a comprehensive model for understanding social networks for working mothers. However, models and research regarding work-family integration must still be reviewed and critiqued as possible theoretical frameworks for understanding support constructs in the workplace to best understand the complexity of research related to formal social workplace networks for working mothers.

\section{CONCLUSION}

A review of the literature indicates that philosophical and research perspectives are dominated with problem-oriented views of work-life balance and attrition issues related to working mothers. Little information or insight exists on the positive aspects and social supports inherent in the experience, which leads to many questions related to the centrality of this phenomenon. The purpose of this paper was to explore the literature and provide a 
conceptual framework for workplace social networks for working mothers. The significance of this theoretical exploration lies in its integration of the literature and analysis of related existing theories. This manuscript acknowledges the considerable diversity in the literature and contexts concerning working mothers. Further investigation is needed to bridge the gap between policy and operation, perhaps through innovative interventions, mentoring, outreach, community partnerships, and best practices exploration of formal workplace social networks for working mothers. Meanwhile, any research related to the effectiveness of support networks for working mothers, whether from the point of view of the participants or the employer, must be grounded in a theoretical perspective that considers women's values and ways of knowing and making meaning of their life experiences.

\section{AUTHOR INFORMATION}

Jennifer L. Schultz is an assistant professor for Human Resource Management (HRM) in the College of Management at Metropolitan State University in Minneapolis, Minnesota. She serves as the Curriculum Coordinator for the undergraduate HRM program and teaches graduate and undergraduate courses in management and HRM.

Jeanne L. Higbee is a professor in the Department of Postsecondary Teaching and Learning in the College of Education and Human Development at the University of Minnesota. She teaches graduate courses in college student development and social justice pedagogy. She is an American College Personnel Association (ACPA) - College Student Educators International Diamond Honoree and recipient of the ACPA Voice of Inclusion Medallion and Disability Ally Award, the College Reading and Learning Association Robert Griffin Award for Long and Outstanding Service, and the Henry Young Award for Outstanding Individual Contribution to the National Association for Developmental Education.

\section{REFERENCES}

1. Bacharach, S. B. (1989). Organizational theories: Some criteria for evaluation. Academy of Management Review, 14, 496-515.

2. $\quad$ Berger, M. (1994). Women beyond Freud: New concepts of feminine psychology. New York: Brunner/Mazel.

3. Clark, S. C. (2000). Work/family border theory: A new theory of work/family balance. Human Relations, 53, 747-770.

4. Cohen, D., \& Prusak, L. (2001). In good company. How social capital makes organizations work. Boston: Harvard Business School Press.

5. Coleman, J. S. (1988). Social capital in the creation of human capital. American Journal of Sociology, 94 (Suppl.), S95-S120.

6. Edwards, J. R., \& Rothbard, N. P. (2000). Mechanisms linking work and family: Clarifying the relationship between work and family constructs. Academy of Management Review, 25, 178-199.

7. Fitzgerald, L. F., Fassinger, R. E., \& Betz, N. E. (1995). Theoretical advances in the study of vocational psychology. In W. B. Walsh \& S. H. Osipow (Eds.), Handbook of vocational psychology. Hillsdale, NJ: Erlbaum.

8. Frone, M. R. (2003). Work-family balance. In J. C. Quick \& L. E. Tetrick (Eds.), Handbook of occupational health psychology (pp. 143-162). Washington, DC: American Psychological Association.

9. Frone, M. R., Russell, M., \& Cooper, M. L. (1992). Antecedents and outcomes of work-family conflict: Testing a model of the family-work interface. Journal of Applied Psychology, 77, 65-78.

10. Gilligan, C. (1982). In a different voice. Cambridge, MA: Harvard University Press.

11. Googins, B. K. (1997). Shared responsibility for managing work and family relationships: A community perspective. In S. Parasuraman \& J. H. Greenhaus (Eds.), Integrating work and family: Challenges and choices for a changing world (pp. 220-231). Westport, CT: Quorum.

12. Gouldner, A. (1959). Reciprocity and autonomy in functional theory. In L. Gross (Ed.), Symposium on sociological theory (pp. 241-210). New York: Harper and Row.

13. Greenhaus, J. H., \& Allen, T. D. (2006, March). Work-family balance: Exploration of a concept. Paper presented at the Families and Work Conference, Provo, UT.

14. Greenhaus, J. H., \& Beutell, N. J. (1985). Sources of conflict between work and family roles. Academy of Management Review, 10, 76-88. 
15. Greenhaus, J. H., \& Powell, G. N. (2006). When work and family are allies: A theory of work-family enrichment. Academy of Management Review, 31, 72-92.

16. Grzywacz, J. G. (2002, February). Toward a theory of work-family facilitation. Paper presented at the Persons, Processes, and Places: Research on Families, Workplaces, and Communities Conference, San Francisco, CA.

17. Grzywacz, J. G., \& Carlson, D. S. (2007). Conceptualizing work-family balance: Implications for practice and research [Special edition]. Advances in Developing Human Resources, 9, 455-471.

18. Grzywacz, J. G., \& Marks, N. F. (2000). Reconceptualizing the work-family interface: An ecological perspective on the correlates of positive and negative spillover between work and family. Journal of Occupational Psychology, 5, 111-126.

19. Halpern, D. F. (2005). Psychology at the intersection of work and family: Recommendations for employers, working families, and policymakers. American Psychologist, 60, 397-409.

20. Higgins, M., \& Kram, K. (2001). Reconceptionalizing mentoring at work: A developmental network perspective. Academy of Management Review, 26, 284-288.

21. Kanter, R. M. (1977). Men and women of the corporation. New York: Basic Books.

22. Kanter, R. M. (1983). The change masters. New York: Simon \& Schuster.

23. Kram, K. (1985). Mentoring at work: Developmental relationships in organizational life. Glenview, IL: Scott, Foresman.

24. Levinson, D. J. (1978). The seasons of a man's life. New York: Knopf.

25. Lyness, K. S., \& Thompson, D. E. (2000). Climbing the corporate ladder: Do female and male executives follow the same route? Journal of Applied Psychology, 85, 86-101.

26. Miller, J. B. (1976). Toward a new psychology of women. Boston: Beacon Press and Boston National Education Association.

27. Miner, J. B. (2002). Organizational behavior: Foundation, theories, and analyses. New York: Oxford University Press.

28. Morris, M. L., \& Madsen, S. R. (2007). Advancing work-life integration in individuals, organizations, and communities [Special edition]. Advances in Developing Human Resources, 9, 439-454.

29. Paludi, M. A., \& Neidermeyer, P. E. (2007). Work, life, and family imbalance: How to level the playing field. Westport, CT: Praeger.

30. Pitt-Catsouphes, M., Kossek, E. E., \& Sweet, S. (2006). The work and family handbook: Multi-disciplinary perspectives and approaches. Mahwah, NJ: Lawrence Erlbaum.

31. Piotrkowski, C. S. (1979). Work and family systems. New York: Free Press.

32. Repetti, R. L. (1987). Linkages between work and family roles. Applied Social Psychology Annual, 7, 98127.

33. Schreiber, P. J. (1998). Women's career development patterns. In L. L. Bierema (Ed.), Women's career development across the lifespan: Insights and strategies for women, organizations, and adult educators (pp. 5-13). San Francisco: Jossey-Bass.

34. Staines, G. L. (1980). Spillover versus compensation: A review of the literature on the relationship between work and nonwork. Human Relations, 33, 111-129.

35. Super, D. (1957). The psychology of careers. New York: Harper Collins.

36. Voydanoff, P. (2005, December). The effects of community demands, resources, and strategies on the nature and consequence of the work-family interface: An agenda for future research. Family Relations, 54, 583-595.

37. Watkins, K., \& Marsick, V. (1992). Building the learning organization: A new role for human resource developers. Studies in Continuing Education, 14(2), 115-129.

38. Wentling, R. M. (1998). Work and family issues: Their impact on women's career development. In L. L. Bierema (Ed.), Women's career development across the lifespan: Insights and strategies for women, organizations, and adult educators (pp. 15-24). San Francisco: Jossey-Bass.

39. Zedeck, S. (1992). Work, families, and organizations. San Francisco: Jossey-Bass.

40. Zedeck, S., \& Mosier, K. (1990). Work in the family and employing organization. American Psychologist, 45, 240-251. 